\title{
Constructing English Teaching Environment in New Type of College Campus at the E-times --- A Case Study of College English Teaching Reform in Linyi University
}

\author{
Huaru Chen \\ Foreign Language School, Linyi University \\ Linyi 276005, Shandong, China \\ E-mail: chenhuaru81@163.com
}

Received: March 24, 2011 Accepted: April 20, 2011 doi:10.5539/ass.v7n8p252

\begin{abstract}
Under the great environment of E-times, construction of the new type of college English teaching environment can change the traditional mode centered with classroom teaching and helps to establish a language teaching mode with combination of classroom training and extracurricular independent learning that corresponds with the cognitive rule of students. Based on case of the reform in College English teaching in Linyi University, the author proposed several conceptualizations for building the new type of college campus English teaching environment.
\end{abstract}

Keywords: E-times, Teaching environment, College English, Reform

E-times refers to the electronic times, which also refers to the times in which network is generally used in office, life and all other fields. Under the great environment of E-times, the newly born network and telecommunication technology are impacting the traditional teaching mode of college English teaching and the obsolete foreign language teaching environment can no longer satisfy the requirement of the times. Thus, it is imperative to set up in the college campus a new type of college English language teaching environment that takes the multi-media as the carrier and the network teaching as the center. "College English Curriculum Requirements" that was issued by the Ministry of Education in 2004 and the NO. 1 Document by the Ministry of Education in 2005 proposed the spirit of vigorously pushing forward college English learning based on computer and campus network, setting up individualized teaching system and practically improving the overall English application capacity of college students. Ever since 2005, all colleges and universities across the country set about setting up networking English teaching environment and building digitalized campus on the basis of hierarchical teaching. Let's take Linyi University as the example. In the past five years, this university has altogether made an investment worthy of almost 13 million RMB to purchase the English teaching and management platform with such functional modules of interactive teaching, independent learning and supervision, network testing, backstage recording and performance management, bring in the English learning resource tool with quite a huge amount of learning resources with an integration of resource download, synchronous assistance and online self-testing, install a test system with the functions of man-machine conversation and online testing, which have offered a short-cut and highly effective learning platform for individualized and independent learning of students. The university has established a teaching mode with combination of the classroom teaching with the carrier of computer, multi-media and digitalized teaching and individualized independent learning, which generates a course teaching system with the major content of English language knowledge and language application capacity and learning tactics as well as human quality. Change of the teaching environment requires college English teachers to rapidly change their concepts and transfer from the traditional teaching mode of "teaching material-blackboard-chock" to the new mode of college English teaching with assistance of the multi-media network. That is to say, to transfer to the new type with combination of the classroom training under assistance of modernized teaching and extracurricular independent learning.

\section{To set up a classroom environment of college English teaching assisted by the multi-media}

Firstly, in the form of classroom teaching, the classroom of college English teaching assisted by the multimedia should change the traditional classroom teaching means with the center of text and teachers, set up a new type of classroom teaching mode with the center of students and form the independent, cooperative and research 
learning approach. This kind of classroom teaching ought to positively hold the various forms of classroom discussion, language competition and cultural activities and alter the former procedure in which teachers illustrate and students learn passively. In the entire process of classroom teaching, the language teaching method that is set up and corresponds with the cognitive rule of students enables students to learn from the easy to the difficult and from the simple to the comprehensive and gradually recognize, understand and grasp, which is helpful to mobilize the learning enthusiasm and initiative of students, helps students in their independent learning, cooperative learning and research learning and is helpful for cultivation of the practical capacity and innovative capacity of students. At the level of practical training of language foundation, this sort of teaching mainly adopts the teaching method of independent exploration and self-diagnosis, give full play to the learning initiative of students, and let students continue to acquire language basic knowledge and skills in the process of self evaluation and evaluation by teachers, motivated by the task.

Secondly, in terms of teaching content, the classroom teaching of college English fully adopts the method with combination of teachers' instruction in the classroom and independent training of students after the class. In the classroom, teachers mainly illustrate and demonstrate skills and evaluation skills, fully take the advantage of multi-media courseware and online video material in the actual context, regard the learning theory of humanism and constructivism as the foundation, resort to the interactive advantage of network, set up a new type of foreign language teaching mode with combination of "multi-media assisting classroom teaching + online independent learning" on the basis of giving priority to the teaching content, and make teaching content with stronger interaction and pertinence, which can greatly improve the learning initiative of students and enhance their learning performance, which, in turn, is able to achieve the target of improving the teaching quality.

Finally, the training of simulation and practical application should be conducted in the classroom teaching. Implementation of this training is mainly centered with students, directed by teachers and oriented by knowledge and skill. Foreign language learning has to start out from development of skills, pay attention to the training and acquisition of practical application capacity of students, change from the former single classroom teaching to offer omnibearing teaching service for students, attempt to build a multi-angle and stereo language learning environment with organic combination of learning and practice and transfer the process of learning language knowledge and acquiring skills to the process of actual intercultural communication. For example, in the college English reading and vocabulary teaching, we can encourage students to search the background data of an article with the materials provided by the teachers and compose the playlet of their own by themselves or with assistance of the network according to certain story plot in the teaching material. We can also let students to have a debate about the content of a text and put forward their own opinions or viewpoints. Teachers have to provide exercise with different difficulties of knowledge at different stages according to students' different language level. Students can also select exercise that suits with themselves according to their own situation, which can not only practically cultivate the practical capacity of students, but can also realize seamless connection between teaching and practical application, which is able to enhance the training effects of students to a large extent.

\section{To set up the extracurricular independent learning environment under the network environment}

\subsection{To set up "Blog teaching and communication platform"}

According to the characteristics of curriculum hyper text of network course, learners are able to rapidly and conveniently convey and receive information through network and multi-media computer and select the information they require and favor to learn (Chen Jianlin, 2004). Let's take Linyi University as the example. Each college English teacher in this university has set up an individual "Blog teaching and communication platform". "Blog teaching and communication platform" includes information distribution of teaching, resource download, online interactive communication, special subject of learning methods, online office, teaching service and so on. Teachers upload to the network the curriculum teaching syllabus, teaching progress plan, hot issue of a chapter, literature review, teaching requirement, extracurricular homework, courseware and so on. By contrast, students can learn by themselves according to the message left by the teachers and the chapters on the discussion board and can also communicate with teachers or other students by the means of publishing an article or replying to a post. "Blog teaching and communication platform" is able to form complete system of teaching, learning, training and exam together with extracurricular training. This sort of teaching and communication platform is able to let students become active providers of the teaching content, but not merely passive receivers, which guarantees improvement of the teaching quality.

\subsection{Network independent learning and monitoring}

He Kekang (2005) pointed out, online courses are courses based on Web under the guidance of advanced educational thinking, teaching theory and learning theory. However, in order to fully embody the advancement of 
online learning in the process of teaching, we have to set up perfect monitoring mechanism. Thus, at the time of establishing online independent learning platform, colleges and universities should also set up online teaching and management platform, online teaching comprehensive platform or online testing platform, which can offer effective guarantee for students to learn with individualism and for teachers to monitor and answer question and conduct evaluation on students' learning. Taking Linyi University as the case study. This university has installed the following huge amount of learning resources: the training software of "New Era Interactive English" published by Tsinghua University Press, "College English learning system" published by Higher Education Press, Pigeon English Online, Yaxinda Intelligence English Learning Platform, Digitalized Audio Visual Resource Pool and Yinfu Level Passing Exam Simulation Platform, which realizes the individualism of online teaching and the English teaching mode with integration of "teaching, learning, exam training and exam". In the aspect of constructing independent learning and monitoring system, this university implements the method of answering questions by teachers online through long distance. Teachers are able to know clearly the attendance situation of students' independent learning, sub-item performance and the time of answering a question, etc, and teachers are able to correct students' audio oral homework that is uploaded through the network. The reliable online teaching and monitoring system can not only guarantee the successful implementation of online independent learning, but can also promote organic integration of modern educational technology and college English courses.

\subsection{Extracurricular training and portfolio system}

Extracurricular training adopts the method of "target management and quantified decomposition of learning task" to decompose the extracurricular training content of such courses as oral English, listening, reading, vocabulary, writing and so on, which allows for enough learning time and exam weight. Implementation of the portfolio system means that students place on file the extracurricular English training and learning material and relevant records and regularly put them into the portfolio. It is the teachers who make stipulations on the material and content contained in the portfolio and track the learning process of students in the process of teaching and provide guidance and evaluation. This has positive monitoring and promotion effect upon the long term independent learning of students.

\section{Achievements gained in college English teaching reform under the multi-media network environment}

With five years' practice, reform on the college English teaching mode under the multi-media network environment in Linyi University has achieved its periodical achievements. College English teaching has not only enabled the students to have a systematic fundamental skill training in listening, speaking, reading, writing, translation and teaching, but also has enhanced to a large extent students' practical capacity and comprehensive qualities.

Firstly, the one-off passing rate of Band 4 National English Exam in this university has kept above $70 \%$ in the last three years, more than 40 percentage points higher than the average one-off passing rate of the peer universities across the country in the last three years. In the past three years, students in this university have achieved glorious achievements in all sorts of English competitions at a national, provincial and municipal level. Altogether, they have gained 15 provincial rewards and 9 municipal rewards. The reform of college English teaching has also driven promotion of the teaching reform of English major and Russian major. In the past three years, the students of English major have achieved encouraging achievements in the TEM 4 and TEM 8 (Test for English Majors Grade 4 and Test for English Majors Grade 8). Their average score in the TEM 4 is more than 30 percentage points higher than that of the peer universities. And the average score in the TEM 8 is more than 20 percentage points higher than that of the peer universities.

On the basis of utilizing network resources, college English courses also set up comprehensive improvement module for those students who take part in the entrance exams for postgraduate schools, put forth efforts to strengthen the English foundation of students and improve their exam-oriented education capacity by means of setting up follow-up improvement courses (advanced English reading and writing and advanced audiovisual English) and special tutoring for postgraduate English. The rate of enrolling postgraduates in the past five years has been kept around $45 \%$.

Then, in the last five years, foreign language teachers in this university have continued to update knowledge and improve their own quality in the process of utilizing advanced modern educational technology to teach college English. Thus, their teaching and scientific research technical capacity and level has got improved and they have attained abundant teaching and scientific research achievements, altogether writing 93 papers on teaching, among which there are 52 influential teaching papers that have been accepted by CSSCI and Guide to Core Journals of China. 


\section{Conclusion}

To sum it up, under the E-times environment, establishment of the new type of college English teaching environment changes the traditional mode which "takes the classroom, the text and the teachers as the center". Furthermore, the teaching and management mode based on network and multi-media is easy to apply, participate and communicate, with strong interaction, can overcome quite a lot of disadvantages in the traditional college English teaching and can achieve the purpose of teaching students in accordance with their aptitude, adjusting measures to local conditions and individualized learning of students. The new type of foreign language learning environment can also greatly stimulate the learning interests among students. At the same time, the college English teaching has presented the vitality of teaching in a new era. However, we have to acknowledge that, there still exist some problems that are urgently awaiting resolution in the process of setting up the new type of college English teaching environment. Thus, we have to continue to reform the teaching content and teaching method of college English, organize teaching according to the advanced international teaching mode, evaluation and exam method, and push forward the reform of modernized teaching environment in college English teaching on the basis of fully referring to and taking in the excellent curricular design modes in universities of foreign countries.

\section{References}

Chen, Jianlin. (2004). Theoretical Connotation and Application Analysis of College English Network Teaching. Computer-assisted Foreign Language Education, (6):46-50.

Department of Higher Education of Ministry of Education. (2004). College English Curriculum Requirements. Shanghai: Shanghai Foreign Language Education Press.

He, Kekang. (2005). Design and Development of Modern Education Technology and Excellent Network Course. China University Teaching, (1):16-21. 